\title{
ASPECTOS CRÍTICOS DEL RÉGIMEN SANCIONATORIO DE LOS CONTRATOS ADMINISTRATIVOS
}

\author{
CRITICAL ASPECTS OF THE PENALTY REGIME IN THE FIELD \\ OF PUBLIC PROCUREMENT
}

ROSA FERNANDA GÓMEZ GONZÁLEZ***

\section{RESUMEN}

El presente trabajo tiene por objeto analizar, en términos generales, el régimen de las sanciones contractuales en los contratos administrativos en Chile, dando cuenta de los aspectos críticos más relevantes. El estudio sostiene que tanto la regulación de las sanciones en las bases y contratos administrativos, así como su aplicación, atendido su carácter de acto administrativo desfavorable, debe observar un régimen jurídico de Derecho público, por lo que cabe aplicar una serie de principios, derechos y garantías de ese orden, como contradictoriedad, proporcionalidad, motivación e impugnabilidad.

Palabras clave: Sanciones contractuales, Multa, Ius puniendi, Régimen jurídico, Derecho público, Incumplimiento, Potestades exorbitantes, Discrecionalidad.

* Profesora de Derecho Administrativo, Pontificia Universidad Católica de Valparaíso, Valparaíso, Chile. Doctora en Derecho, Pontificia Universidad Católica de Valparaíso, Chile. Correo electrónico: rosa.gomez@pucv.cl. ORCID: https://orcid.org/0000-0003-4769-6749.

** Esta investigación cuenta con el apoyo del Proyecto FONDECYT Postdoctoral No 3190494 "Sanciones administrativas y derechos fundamentales. Análisis de temas específicos a partir de los principios, garantías y derechos regulados en la Constitución" y del FONDECYT Regular No 1201868 "Criterios y estándares para el control de la potestad sancionadora de la Administración: análisis de los mecanismos de revisión judicial y administrativa". Asimismo, cuenta con el apoyo del proyecto de investigación "Derecho Administrativo Sancionador 2.0" (2018-RTI-096688-B-100), Proyecto I+D+i «Retos Investigación» 2018, del Ministerio de Ciencia, Innovación y Universidades de España y del Fondo Europeo de Desarrollo Regional (FEDER).

Artículo recibido el 7 de marzo de 2021, y aprobado para su publicación el 15 de junio de 2021. 


\section{ABSTRACT}

The present work aims to analyze, in general terms, the contractual sanctioning regime in administrative contracts in Chile, giving an account of the most relevant critical aspects. The study maintains that both the regulation of sanctions in the administrative bases and contracts, as well as their application, given its character as an unfavorable administrative act, must observe a legal regime of public law, so that a series of principles, rights and guarantees of that order, such as contradictoriness, proportionality and impugnability.

Keywords: Contractual sanctions, Fine, Ius puniendi, Legal regime, Public law, Non-compliance, Exorbitant powers, Discretion.

\section{INTRODUCCIÓN}

En materia de contratación pública, nuestro ordenamiento jurídico se caracteriza por la ausencia de una regulación general o de base que precise los aspectos estructurales que deben informar la actividad contractual de los órganos de la Administración del Estado. Por el contrario, nuestro sistema se caracteriza por la existencia de regulaciones especiales en atención a cada tipo de contrato. Así, la variedad de contratos celebrados por la Administración es considerable, teniendo muchos de ellos el carácter de innominados.

Ahora bien, una de las características más relevantes de un contrato administrativo está dada por su particular marco normativo y por la existencia de potestades exorbitantes en manos de la Administración.

El marco normativo de un contrato público no se compone solo de la ley específica que lo regula y de su reglamento, sino que forman parte de él las bases de licitación, las modificaciones aportadas a estas, la oferta, las prescripciones técnicas, ${ }^{1}$ así como las consultas y respuestas que se hayan

\footnotetext{
${ }^{1}$ V. Corte Suprema, 4 de diciembre de 2018, "Sodexo Servicios S.A. con JUNAEB", Rol No 45.578 2017, cons. $10^{\circ}$; Corte Suprema, 30 de enero 2017, "De Marco S.A. con I. Municipalidad de Maipú", Rol No 16.629-2016, cons. $12^{\circ}$; Corte Suprema, 8 de noviembre 2019, "Scolarest S.A. con JUNAEB", Rol No 16.345-2018, cons. 13" ; y Corte Suprema, 23 de julio de 2020, "Servicios Sitrack Chile Ltda. con I. Municipalidad de Santiago", Rol No 24.212-2019, cons. $7^{\circ}$, entre otras.
} 
formulado durante el período de formulación de las ofertas. En este punto, si bien la ley y el reglamento fijan los aspectos medulares de iter contractual, las bases son el aspecto definitorio del contrato, esto es, son el acto que le proporciona una identidad propia, acorde con la necesidad pública que se busca satisfacer a través de este.

Por su parte, la relación jurídica en un contrato administrativo se caracteriza por la desigualdad de las partes y por la existencia de poderes exorbitantes en manos de la Administración, colocando a ésta en una posición de superioridad frente al contratista particular, la cual encuentra su justificación en el interés público. A través de estas prerrogativas la Administración asegura la buena y correcta ejecución del contrato público.

Para efectos de este trabajo, se pondrá el énfasis en la potestad sancionadora que tienen los órganos de la Administración en materia contractual, la cual constituye una potestad exorbitante conforme a la cual el servicio tiene una doble función, por una parte, tipificar las conductas constitutivas de infracción contractual y sus sanciones ${ }^{2} \mathrm{y}$, por la otra, instruir el procedimiento sancionatorio e imponer las sanciones respectivas.

\section{SOBRE LA NATURALEZA JURÍDICA DE LAS SANCIONES CON- TRACTUALES}

\section{Análisis dogmático y jurisprudencial}

Existe cierto consenso en orden a que las sanciones contractuales tienen su origen en un incumplimiento de naturaleza contractual, constituyendo una consecuencia jurídica de una situación expresamente prevista en las bases y en el contrato administrativo, que no implica el ejercicio del ius puniendi o potestad sancionatoria del Estado. En otros términos, el establecimiento de sanciones en el contrato serían meras cláusulas penales, esto es, una evaluación anticipada de los perjuicios.

Al efecto, la Contraloría General de la República ha señalado que el fundamento de la imposición de multas en el marco de la ejecución

\footnotetext{
${ }^{2}$ Sin perjuicio de que, en algunos casos, normas contractuales especiales contemplan ilícitos y establecen sanciones. V. gr: Alarcón, Pablo, "Sanciones Administrativas en el Contrato de Construcción de Obra Pública", en Arancibia, Jaime; Alarcón, Pablo (coords.), Sanciones Administrativas, Legal Publishing, Santiago, 2014, pp. 361-368.
} 
de un convenio celebrado por la Administración dice relación con un incumplimiento contractual y no con una infracción administrativa, de modo que aquellas medidas, no revisten la calidad de una sanción administrativa, sino que constituyen una consecuencia jurídica de una situación expresamente prevista en las bases y en el contrato, que no implica el ejercicio del ius puniendi o potestad sancionatoria del Estado. ${ }^{3}$ De esta forma, las estipulaciones contractuales que contienen multas asociadas al incumplimiento de las obligaciones convencionales son cláusulas penales, ${ }^{4}$ definidas en el artículo 1535 del Código Civil como aquella en que una persona, para asegurar el cumplimiento de una obligación, se sujeta a una pena, que consiste en dar o hacer algo en caso de no ejecutar o retardar la obligación principal. ${ }^{5}$

Este criterio, en principio, impone un régimen jurídico de Derecho privado a las sanciones administrativas contractuales, lo que excluiría la aplicación de las normas y principios de Derecho público. Sin embargo, se trata una aplicación parcial que no permite el recurso a otras instituciones de Derecho civil, ${ }^{6}$ que no es consistente con las potestades exorbitantes que posee la Administración y que deja al contratista en una manifiesta situación de desigualdad e indefensión, por cuanto la misma autoridad que tipifica las contravenciones y establece las correspondientes sanciones es, también, la que aplica dichas medidas.

Ahora bien, en la jurisprudencia judicial es posible encontrar posiciones diversas. En algunos fallos, la Corte Suprema ha señalado que las sanciones contractuales no corresponden al ejercicio de la potestad sancionadora de la Administración, sino que el cumplimiento de un contrato constituye "una ley para las partes". ${ }^{7}$ Por su parte, en otros pronunciamientos, la Corte

\footnotetext{
${ }^{3}$ Contraloría General de la República, Dictamen No 65.248, de 2011; Dictamen N ${ }^{\circ} 21.035$ de 2012; Dictamen $N^{\circ}$ 50.606, de 2012; Dictamen N 34.523 de 2013; Dictamen $N^{\circ}$ 47.611, de 2013; Dictamen $\mathrm{N}^{\circ}$ 65.791, de 2014; Dictamen $\mathrm{N}^{\circ}$ 1.765, de 2015; Dictamen $\mathrm{N}^{\circ}$ 50.347, de 2015; Dictamen $\mathrm{N}^{\circ} 61.075$ de 2016; Dictamen N ${ }^{\circ}$ 74.275, de 2016.

${ }^{4}$ Contraloría General de la República, Dictamen N 96.251, de 2015.

${ }^{5}$ Contraloría General de la República, Dictamen Nº 65.788 de 2014; Dictamen Nº5.791 de 2014.

${ }^{6}$ V. gr., Contraloría General de la República, Dictamen $N^{\circ} 26.263$ de 2009, el ente contralor sostuvo, respecto de la excepción de contrato no cumplido que "(...) la aplicación de multas por parte de la Administración del Estado deriva del conjunto de potestades con que ésta ha sido dotada por el ordenamiento jurídico en el ámbito de los contratos administrativos, las que no son propias del ámbito contractual, de modo que a su respecto no se aplica el artículo 1.552 del Código Civil”.

${ }^{7}$ Corte Suprema, 25 de julio de 2019, "CAS Chile S.A. con I. Municipalidad de La Pintana”, Rol N ${ }^{\circ}$ 11.527-2019, cons. $9^{\circ}$. Por su parte, en sentencia de la Corte Suprema, 24 de enero de 2020, "Concesiones
} 
Suprema, refiriéndose a los contratos regulados por la Ley $\mathrm{N}^{0} 19.886$, ha señalado que la imposición de la multa contractual importa el ejercicio de la potestad sancionadora como manifestación propia del ius puniendi estatal:

“(...) la aplicación de una multa impuesta por la Administración en el marco de los contratos administrativos de la Ley $\mathrm{N}^{\circ}$ 19.886, constituye una sanción administrativa o bien una manifestación de la potestad sancionadora de la Administración, en tanto se trata de una reacción que el ordenamiento atribuye a un obrar que se considera ilícito en el contexto de una relación de Derecho Público, cuestión por la que en definitiva se persigue reponer un equilibrio que se ve quebrantado con motivo del incumplimiento del contratista y que se materializa a través de un acto administrativo. De lo dicho, se sigue que la multa contractual se condice con la imposición de una sanción administrativa que la autoridad pública impone a un particular en cuanto se haya verificado un supuesto de infracción normativo, contractual o a las bases de licitación". ${ }^{8}$

Por su parte, en relación con la naturaleza jurídica de las sanciones contractuales la doctrina se encuentra divida básicamente en las siguientes posiciones:

Para algunos, las sanciones contractuales no son sanciones administrativas. Así, el poder de aplicar dichas sanciones es distinto del ejercicio de la potestad sancionadora general, por cuanto la atribución de aplicar las sanciones contractuales se da en el contexto de un contrato, correspondiendo en su naturaleza jurídica a verdaderas las cláusulas penales que puede aplicar directamente la Administración contratante, en el ejercicio de los poderes de autotutela que le reconoce ordenamiento jurídico. ${ }^{9}$ De esta manera, las sanciones contractuales no serían parte del Derecho Administrativo Sancionador, sino que se tratarían de cláusulas penales de

Recoleta S.A. con I. Municipalidad de Recoleta”, Rol No 251-2019, el máximo tribunal sostuvo que las multas aplicadas por la municipalidad en ejercicio de las facultades contractuales no son revisables mediante reclamo de ilegalidad porque la sanción no emana de la potestad sancionadora.

${ }^{8}$ Corte Suprema, 21 de diciembre de 2017, "Espacio y Jardín Ltda. con I. Municipalidad de Iquique”, Rol No 4.001-2017, cons. $5^{\circ}$ (sentencia de reemplazo).

9 Bermúdez, Jorge, Derecho administrativo general, Legal Publishing, Thomson Reuters, La Ley, Santiago, 2014, $3^{\text {a }}$ edición, pp. 279-280. 
carácter civil. ${ }^{10}$

Esta misma idea ha sido recogida a nivel comparado. Así, en España, las multas han sido establecidas respecto de incumplimientos no sustanciales $\mathrm{y}$ en todos los casos de demora en que no concurra culpa del contratista, ${ }^{11}$ negando su naturaleza punitiva o sancionadora y considerándolas como similares a las obligaciones con cláusula penal, siendo su objeto estimular el cumplimiento de la obligación principal. ${ }^{12}$ Para la doctrina, lo característico del contrato administrativo radica en que la imposición de "penalidades" al contratista constituye un poder de la Administración establecido directamente por la ley, ${ }^{13}$ que no requiere de una inclusión explícita en los pliegos de cada contrato. En otros términos, se trata de una potestad de la Administración que carece del carácter formalmente sancionador. ${ }^{14}$

Para otros autores, se trataría de un régimen disciplinario, en donde el contratista se encontraría sometido a un régimen de sujeción especial respecto de la Administración. La multa sería la sanción que se impone como castigo por conductas contrarias al contrato y que afectan la disciplina interna que rige la relación entre las partes. ${ }^{15}$

Para otra parte de la doctrina, las sanciones contractuales serían

${ }^{10}$ Lledó, Camilo; PARdo, José, "Sistema de sanciones por incumplimiento en los contratos públicos de suministro y prestación de servicios: la incerteza como un problema de política pública", Revista de Derecho Público, 2015, Vol. 82, pp. 66 y ss. Con todo, estos autores sostienen que considerar las multas contractuales como una manifestación de un derecho contractual, no implica "(...) una autorización para que la Administración actúe en forma arbitraria (como si se tratara de un derecho subjetivo particular que puede ser ejercido en el exclusivo interés del órgano contratante). Por el contrario, tanto en base a las normas civiles como en especial a los principios generales del Derecho Público, los órganos públicos siempre deben respetar (sea que actúen mediante actos administrativos o no) ciertas garantías de buena fe en su actuación con los particulares, así como una adecuada proporcionalidad, finalidad y razonabilidad en su actuar". En otros términos, para estos autores los “(...) principios de proporcionalidad, finalidad, razonabilidad y buena fe trascienden la escrituración de las bases, por lo que debieran entenderse por sobre el principio de estricta sujeción a las bases. Es decir, estos principios se encuentran envueltos en toda la actividad administrativa y no son exclusivos del Derecho Administrativo Sancionador (como podría entenderse de cierta doctrina que defiende la aplicación del Derecho Administrativo Sancionador en esta materia)", p. 70.

${ }^{11}$ Muñoz Machado, Santiago, Tratado de Derecho Administrativo y Derecho Público general, Boletín Oficial del Estado, Madrid, 2015, Tomo XIII (Contratos del Sector Público), $4^{\mathrm{a}}$ edición, pp. 190 y ss.

${ }^{12}$ Sentencia del Tribunal Supremo (España), 18 de mayo de 2005.

${ }^{13}$ Actualmente reguladas en los artículos 192 y siguientes de la Ley 9/2017, de 8 de noviembre, de Contratos del Sector Público.

${ }^{14}$ Santamaría Pastor, Juan Alfonso, Principios de Derecho Administrativo General, Iustel, Madrid, 2016, 4a edición, p. 268.

${ }^{15}$ Rufián, Dolores, Manual de concesiones de obra pública, Fondo de Cultura Económica, Santiago, 1999, p. 101. 
sanciones administrativas. Así, Lara y García-Huidobro sostienen que las multas contractuales serían sanciones administrativas, cuya imposición debiese respetar los principios y garantías que limitan el ejercicio del ius puniendi del Estado. Par estos autores, la interpretación de la Contraloría implica: i) una infracción al orden de prelación de normas establecido en el artículo $1^{\circ}$ de la Ley $\mathrm{N}^{\mathrm{o}} 19.886$ y ii) un desconocimiento del principio de colaboración de las partes contratantes que debe regir en materias de contratación administrativa. ${ }^{16}$

En tanto, Moraga hace una distinción. Por una parte, el autor sostiene que las sanciones establecidas en la ley o en el reglamento, son expresiones del ius puniendi del Estado, puesto que no son el resultado de una negociación entre las partes. En tanto, respecto de las sanciones establecidas en las bases, sostiene que la situación es más discutible. Con todo, se trata de una potestad pública exorbitante, que no puede ser asimilada a la "cláusula penal" (artículo 1535 del Código Civil), por cuanto las sanciones son creadas unilateralmente por la Administración sin que el contratista pueda imponer una cláusula a su favor. Junto con ello, la sanción que afecta al contratista no responde a una "indemnización", el quantum de la sanción es discrecional para la Administración sin que tenga un vínculo directo, objetivo o científico con el perjuicio que la conducta del contratista pueda generar para el órgano público. ${ }^{17}$

Finalmente, hay autores que, haciendo presente las diversas posiciones que existen sobre la materia, reconocen que las sanciones contractuales se encuentran sujetas a límites derivados de la constitucionalización del Derecho público, $v$. $g r$. el principio de proporcionalidad. ${ }^{18}$

En definitiva, de lo expuesto, se puede concluir que existe una tesis dominante, conforme a la cual las sanciones contractuales son meras

\footnotetext{
${ }^{16}$ Lara, José Luis; García-Huidobro, Luis Eugenio, "Naturaleza jurídica y proporcionalidad de las multas en la contratación administrativa bajo la Ley N ${ }^{\circ} 19.886$ ", en ArANCIBIA, Jaime; AlARcón, Pablo (coords.), Sanciones Administrativas, Legal Publishing, Santiago, 2014, pp. 378 y ss. En este mismo sentido Corral, Hernán, La "cláusula penal". Función y eficacia del contrato penal en el Derecho Chileno, Editorial Jurídica de Chile, Santiago, 2012, p. 357, y Flores, Juan Carlos, “¿Son cláusulas penales las multas en los contratos administrativos?", Contratación Administrativa Práctica, 2021, $\mathrm{n}^{\circ} 173$, pp. 137-151.

${ }^{17}$ Moraga, Claudio, Contratación administrativa, Thomson Reuters, Santiago, 2019, $2^{\text {a }}$ edición, pp. 496 y ss.

${ }^{18}$ RuIz, Andrés, "Límites a la facultad para establecer sanciones en los contratos de la Ley 19.886", en Bermúdez, Jorge (ed.), Perspectivas para la modernización del Derecho de la contratación administrativa, Ediciones Universitarias de Valparaíso, Valparaíso, 2016, p. 296.
} 
cláusulas penales. ${ }^{19}$ Sin embargo, esta posición es más bien instrumental, ${ }^{20}$ parcial e insuficiente para responder a las distintas problemáticas que se suscitan al momento de aplicar el régimen sancionatorio de los contratos. Además, no explica cómo este tipo de clausulas se concilia con los efectos propios de los actos administrativos (legalidad, imperio y ejecutividad) ni con el ejercicio de potestades públicas (v. gr. autotutela declarativa y ejecutiva). ${ }^{21}$

\section{Las sanciones contractuales como sanciones administrativas sometidas a un régimen jurídico de Derecho público}

No cabe duda de que las sanciones contractuales son actos administrativos de carácter desfavorable para el contratista, cuyo origen se encuentra en un incumplimiento o infracción contractual sometida a un régimen jurídico de Derecho público, por lo que es ineludible la aplicación de una serie de principios, derechos y garantías de ese orden, como la contradictoriedad, proporcionalidad, igualdad ante las bases que rigen el contrato, motivación e impugnabilidad. Con todo, en lo no regulado en el régimen contractual especial, sus disposiciones deben ser complementadas con las reglas y principios de Derecho privado.

En este contexto, no es necesario recurrir a un "régimen de Derecho

\footnotetext{
${ }^{19} \mathrm{Al}$ respecto, Flores señala que “( ...) al calificar jurídicamente las multas contractuales como cláusulas penales se refieren a las cláusulas penales punitivas o stipulatio poenae, que en términos dogmáticos tienen por objetivo servir para asegurar la ejecución de las convenciones o para compulsar a los deudores a cumplir con sus obligaciones, ante la amenaza de una sanción por lo común más gravosa. En efecto, la penalidad pactada constituye una sanción, una pena privada que recae en el deudor por el incumplimiento de su obligación.”, en Flores, cit. (n. 16).

${ }^{20}$ Vid. Flores, cit. (n. 16). Para este autor “(...) el auxilio a las normas privadas solo busca utilizar instrumentalmente la cláusula penal como una forma de construir un plazo de prescripción de 5 años de la multa, mucho más amplio que el plazo de 6 meses de las multas penales regulado en el artículo 94 del Código Penal. Sin embargo, no se logra explicar la naturaleza jurídica de las multas impuestas en el contrato administrativo, y a su vez, se niega el carácter potestativo, imperativo y ejecutivo de las multas administrativas, que -a nuestro juicio- no desaparece ni se contractualiza por la existencia de un contrato administrativo.".

${ }^{21}$ Sobre el particular, Flores señala que "Asemejar las multas contractuales a la cláusula penal, con el objetivo despojar a la Administración contratante del régimen de prerrogativa exorbitante de los contratos administrativos, a nuestro juicio solo pretende que la multa contractual quede desprovista de toda formalidad procedimental y ejecutividad. De esta forma, el auxilio al derecho privado es funcional, solo para prescindir de las reglas y principios aplicables a las actuaciones administrativas, al señalar que la multa se ejecuta en razón de una cláusula contractual, y no de una potestad pública”, en Flores, cit. (n. 16).
} 
administrativo sancionador general" para exigir la aplicación de un conjunto de reglas y principios, especialmente si se tiene presente que en nuestro país no existe un "régimen administrativo sancionador general" consolidado, sino que su actual regulación responde a una construcción fundamentalmente jurisprudencial y que, en el ámbito normativo, se caracteriza por una serie de regímenes sancionadores especiales para cada sector de referencia.

En otros términos, el recurso al régimen del Derecho Administrativo sancionador lo es fundamentalmente a las "garantías" sustantivas y procedimentales que existirían en este ámbito, las que principalmente tiene su origen en la Constitución y en las leyes administrativas más relevantes (v. gr. Ley $\mathrm{N}^{\mathrm{o}} 18.575$, Ley $\mathrm{N}^{\mathrm{o}} 19.880$, Ley No 20.285, etc.), siendo aquéllas las que se deben extrapolar al ámbito de las "sanciones contractuales".

De este modo, para resolver esta problemática, no es necesario recurrir como primera fuente, al régimen de Derecho privado. Si bien las cláusulas penales o sancionatorias establecidas en las bases de licitación, en los términos de referencia (en adelante TDR) y/o en los contratos administrativos, encuentran su origen y fundamento en la regulación contenida en el artículo 1535 del Código Civil, ${ }^{22}$ por cuanto se trata de cláusulas establecidas por una de las partes (Administración) con el objeto de asegurar el cumplimiento de una obligación, sujetándose a una pena (sanción), que consiste en dar o hacer algo (generalmente el pago de un multa) en caso de no ejecutar o de retardar la obligación principal, se trata de una regulación que debe ser sometida a las disposiciones de Derecho público, ello en atención a los siguientes argumentos:

a) La naturaleza del contrato administrativo es especial y difiere de la regulación prevista para los contratos de naturaleza privada. En los contratos administrativos si bien hay un acuerdo de voluntades para celebrarlo, no ha existido la libre voluntad para pactar cláusulas y valorar anticipadamente los perjuicios, debido a que las partes no negocian libremente las cláusulas del contrato, existiendo más bien una adhesión y aceptación de cláusulas preestablecidas por la Administración, la que actúa en el ejercicio de

\footnotetext{
${ }^{22}$ Un análisis más detallado de las clausulas penales se puede ver en CORRAL, Hernán, "La cláusula penal en la resolución del contrato" en AlCAlde, Enrique; FÁBrEga, Hugo (coords.), Estudios jurídicos en homenaje a Pablo Rodríguez Grez, Universidad del Desarrollo, Santiago, 2009, pp. 339 y ss.; y Prado, Arturo, "Algunos aspectos de la cláusula penal en el derecho chileno", Revista de Derecho Universidad Católica del Norte, 2019, Vol. № 26, e3893.
} 
potestades públicas (exorbitantes).

b) En el ejercicio de cualquier potestad, particularmente la sancionadora, la Administración debe observar ciertas reglas y principios básicos: i) requiere una habilitación legal; ii) su ejercicio debe perseguir una finalidad pública; iii) el procedimiento a través del cual se impone la medida sancionadora debe cumplir con principios y garantías mínimas, y iv) el acto que la concreta siempre será susceptible de control.

c) Aun cuando se sostenga que se trata de cláusulas penales, la aplicación de sanciones contractuales se debe someter a ciertos estándares. En efecto, su imposición por parte de un órgano administrativo debe sujetarse a la regulación y principios del Derecho público, lo que ciertamente comprende las formalidades establecidas en la ley, las bases y en el contrato, así como por las reglas generales de la contratación, a saber: i) la existencia de una obligación incumplida; ii) la necesaria relación de causalidad del incumplimiento y el perjuicio; iii) culpa o dolo del deudor, lo que en la práctica se traduce en falta de una causal de exención de responsabilidad; iv) la mora del deudor ${ }^{23} \mathrm{y}$ v) la exigencia de un procedimiento legalmente tramitado para su aplicación.

Por ello, estimo que el régimen sancionatorio contractual se debe construir a partir de las reglas y principios que informan la actividad administrativa, a través de la aplicación e interpretación de sus disposiciones y de los derechos y garantías que estructuran e informan el ejercicio de potestades públicas de carácter contractual, lo cual no obsta que pueda ser complementado con ciertos principios y reglas de Derecho privado.

Enseguida, se debe tener presente que, en este ámbito, el fin de la sanción contractual es asegurar el cumplimiento de la pactado, ${ }^{24}$ procurando que el contratista cumpla con las obligaciones que asume en virtud del contrato y, cuando se trata de satisfacer directamente una necesidad pública, que el contratista lo haga bajo estándares preestablecidos. Con ello, se busca la correcta administración de los recursos públicos e impedir, en su caso, la repetición de la conducta infractora. ${ }^{25}$

\footnotetext{
${ }^{23}$ Moraga, cit. (n. 17), pp. 498 y ss.

${ }^{24}$ Lo esencial de un contrato administrativo no es castigar las faltas del contratista, sino que asegurar la realización de un servicio público o construcción de la cosa pública. FARRANDO, Ismael, "Sanciones contractuales", en Farrando, I. (Dir.), Contratos Administrativos, Lexis Nexis, Buenos Aires, 2002, p. 570 .

${ }^{25}$ Moraga, cit. (n. 17), p. 492.
} 
Así, por lo demás, se ha sostenido en la doctrina comparada al señalar que "En la contratación administrativa lo fundamental es que el particular cumpla, sobre todo en los contratos estrechamente vinculados a la ejecución de los servicios, y por ello las sanciones se inspiran en esa finalidad". ${ }^{26}$

En definitiva, las sanciones contractuales son actos administrativos, sometidos a un régimen jurídico de Derecho público, consecuencia de lo cual resultan aplicables una serie de reglas y principios de dicho orden. Lo anterior no excluye la aplicación de ciertos principios y reglas de Derecho privado, especialmente en aquellos casos en los cuales las normas de Derecho público no prevén una regulación especial. En tal sentido, resultan plenamente aplicables el principio de buena fe contractual (artículo $1546 \mathrm{del}$ Código Civil), ${ }^{27}$ la prohibición de enriquecimiento sin causa, el equilibrio económico de las prestaciones mutuas, ${ }^{28}$ las reglas civiles en materia de caso fortuito o fuerza mayor (artículo 45 del Código Civil), ${ }^{29}$ condición resolutoria (artículo 1489 del Código Civil); ${ }^{30}$ proporcionalidad (artículo 1544 del Código Civil) y prescripción (artículos 2492 y ss. del Código Civil). ${ }^{31}$

${ }^{26}$ Sayagués, Enrique, Tratado de Derecho Administrativo, Fundación de Cultura Universitaria, Montevideo, 2015, Vol. I, $10^{\text {a }}$ edición, p. 571.

${ }^{27}$ Contraloría General de la República, Dictamen No 27.910 de 2018; Dictamen Nº 27.913 de 2018.

${ }^{28}$ Contraloría General de la República, Dictamen No 72.427 de 2011; Dictamen No 49.409 de 2012; Dictamen $N^{\circ} 56.435$ de 2015; Dictamen $N^{\circ} 37.515$ de 2017; Dictamen $N^{\circ} 40.163$ de 2017; Dictamen $\mathrm{N}^{\circ} 27.910$ de 2018; Dictamen 27.913 de 2018, entre otros.

${ }^{29}$ Contraloría General de la República, Dictamen No 31.421 de 2018; Dictamen Nํ 6.854 de 2020; Dictamen $\mathrm{N}^{\circ} 90$ de 2021; Dictamen $\mathrm{N}^{\circ}$ E72682 de 2021, entre otros.

${ }^{30}$ Contraloría General de la República, Dictamen No 1.307 de 1985; Dictamen Nº 23.309 de 1986, y Dictamen $\mathrm{N}^{\circ} 12.523$ de 1997.

${ }^{31}$ Sobre el particular, la jurisprudencia administrativa ha indicado que las multas establecidas en las bases de licitación y en los respectivos contratos prescriben conforme a las disposiciones del Título XLII "De la Prescripción", del Libro Cuarto "De las obligaciones en general y de los contratos", del Código Civil. Véase Contraloría General de la República, Dictamen N ${ }^{\circ} 4.508$ de 2013; Dictamen $N^{\circ}$ 65.446 de 2013; Dictamen $N^{\circ} 61.075$ de 2016; Dictamen $N^{\circ} 74.275$ de 2016. En este mismo sentido, véase Corte Suprema, 18 de octubre de 2018, "Mellafe y Salas S.A. con Fisco de Chile", Rol No 38.856-2017. 


\section{EL RÉGIMEN SANCIONADOR CONTRACTUAL}

\section{Características del régimen sancionador contractual}

Una de las principales problemáticas que presenta el régimen sancionador contractual está dada por la ausencia de un régimen sancionatorio general o de base aplicable a los incumplimientos contractuales. Como se ha señalado, la falta de una definición clara de la naturaleza jurídica de dichas sanciones, de sus elementos, del procedimiento de aplicación de estas y de sus límites, a fin de disminuir los riesgos de arbitrariedad por parte de la Administración, ${ }^{32}$ explica, en alguna medida, el recurso al régimen administrativo sancionador general, como sistema supletorio.

Ahora bien, el régimen sancionador contractual dependerá, en primer término, del marco regulatorio contractual específico y, enseguida, de la regulación contenida en las bases de licitación del contrato o, en su caso, de los términos de referencia.

En tal sentido, de la revisión de las diversas disposiciones contractuales especiales, se advierte que existe una mínima regulación legal tanto de las infracciones y sanciones contractuales como del procedimiento al cual se debe sujetar su aplicación, las que quedan entregadas a una regulación más exhaustiva en las bases de licitación y en el contrato administrativo, lo que constituye una amplia discrecionalidad para el órgano público contratante, el que no solo deberá tipificar los incumplimientos y establecer sanciones, sino que también será la entidad encargada de determinar la ocurrencia del incumplimiento e imponer la sanción respectiva.

En cuanto al tipo de medidas, la sanción más común es la multa, sin embargo, hay otras sanciones contractuales más intensas y graves, como la suspensión de ciertos registros o la caducidad del contrato, entre otros.

\section{Régimen jurídico aplicable}

a) Aplicación de un régimen jurídico de Derecho Público

El régimen jurídico aplicable se encuentra compuesto de una serie de disposiciones de diversa jerarquía normativa, encontrando en la cúspide a la Constitución, la cual se refiere al fin y a las funciones que debe procurar

\footnotetext{
${ }^{32}$ Lledó y Pardo, cit. (n. 10), p. 54.
} 
la Administración, como son la satisfacción del bien común y del orden público.

La Carta fundamental impone a los órganos de la Administración del Estado la observancia de los principios de legalidad y reserva de ley y la exigencia de que, para su ejercicio, toda potestad pública debe ser atribuida expresamente (artículos $6^{\circ}$ y $7^{\circ}$ ). Además, la Constitución establece que la Administración debe hacer públicos todos los actos y resoluciones, así como sus fundamentos y los procedimientos que utiliza (inciso $2^{\circ}$ del artículo $8^{\circ}$ ). Enseguida, la Constitución establece que la regulación y los límites a los derechos no pueden afectar su esencia, ni imponer condiciones, tributos o requisitos que impidan su libre ejercicio (artículo $19 \mathrm{~N}^{\circ} 26$ ). Junto con ello, la Constitución establece diversas disposiciones de carácter procedimental como es el derecho a la tutela judicial y al derecho de acceso a la justicia y debido proceso (artículo $19 \mathrm{~N}^{\mathrm{o}} 3$ ), lo que se debe complementar con la existencia de órganos jurisdiccionales o especiales para la resolución de conflictos en materia contractual (artículos 38 y 76).

Enseguida, cabe aplicar lo dispuesto en la Ley $\mathrm{N}^{0} 18.575$, de Bases Generales de la Administración del Estado, la cual contempla una serie de principios aplicables como el de legalidad, responsabilidad, servicialidad, eficacia, eficiencia, coordinación, jerarquía, impugnabilidad, probidad, transparencia, etc. Todo lo cual se debe complementar con lo dispuesto en la legislación administrativa general: la Ley $\mathrm{N}^{\mathrm{o}} 19.880$, sobre procedimiento administrativo; la Ley $\mathrm{N}^{0} 20.285$ sobre publicidad y transparencia; la Ley $\mathrm{N}^{\mathrm{o}} 10.336$ relativa al control de la actividad administrativa por parte de la Contraloría General de la República; la Ley No 18.834 sobre personal, el Decreto Ley $\mathrm{N}^{\mathrm{o}} 1.263$, de 1975, sobre Administración Financiera, entre otros.

Por su parte, la Corte Suprema ha señalado que:

“(...) todo contrato administrativo se rige por sus estipulaciones, por las normas legales y reglamentarias que lo regulan, por las bases de licitación, por la oferta adjudicada y por las demás prescripciones técnicas". 33

En tanto, la Corte de Apelaciones de Santiago ha manifestado que:

${ }^{33}$ Corte Suprema, 24 de julio de 2019, "Duarte Parada con SERVIU Metropolitano”, Rol No 5218-2018, cons. $4^{\circ}$. 
“(...) dentro del marco normativo, se faculta al órgano público requirente a establecer mecanismos de sanción o de multa en caso de incumplimiento del proveedor $\mathrm{y}$, en cuanto acto administrativo, el proveedor sancionado, tiene asimismo el derecho a recurrir de ellas. Lo esencial, es que tanto en la aplicación de multas, como en los procedimientos posteriores a ello, no se apliquen criterios discriminatorios o bien ilegales, que pudieran conculcar garantías constitucionales". ${ }^{34}$

De esta manera, la aplicación de un régimen jurídico de Derecho público a la aplicación de sanciones contractuales tiene como consecuencia que su ejercicio debe observar ciertas reglas y principios básicos, a saber:

- La exigencia de una habilitación legal.

- Que su ejercicio debe perseguir una finalidad pública general. Por ello, la Administración bien podría utilizar otras medidas, como, por ejemplo: la evaluación deficiente del desempeño y cumplimiento del proveedor ( $v . g r$. artículo 94 letra d) del Reglamento de la Ley $\mathrm{N}^{\mathrm{o}}$ 19.886) o la suspensión del registro de proveedores hasta por 2 años (v. gr. artículo $95 \mathrm{~N}^{\mathrm{o}} 2$ del mismo Reglamento)..$^{35}$

- Respetar las reglas y principios que informan el ejercicio de la potestad administrativa de que se trate ( $v . g r$. proporcionalidad).

- La tramitación previa de un procedimiento administrativo, el cual deberá cumplir con ciertos principios y garantías mínimas (v. $g r$. la posibilidad de conocer los incumplimientos imputados y de presentar descargos). ${ }^{36}$

- Que el acto sancionador siempre deberá ser motivado y será susceptible de control (impugnable).

\footnotetext{
${ }^{34}$ Corte de Apelaciones de Santiago, 17 de julio de 2014, "Nipro Medical Corporation con CENABAST", Rol N ${ }^{\circ}$ 93.869-2013, cons. 4 ; Corte de Apelaciones de Santiago, 17 de julio de 2014, "Nipro Medical Corporation con CENABAST (II)", Rol N 148.668-2013, cons. $4^{\circ}$.

${ }^{35}$ Lara y García-Huidobro, cit. (n. 16), p. 398.

${ }^{36}$ En este sentido, se puede citar como ejemplo, el oficio $\mathrm{N}^{\circ} 14.772$, de 2014 , mediante el cual se cursa con alcances el acto allí señalado, y en el cual se indica que "(...) en la letra d) de ese numeral, se indica que la multa será aplicada previo análisis de Fonasa con el centro de diálisis respectivo, lo que ha de entenderse que ese servicio, antes de resolver, deberá tener presente los descargos del proveedor, en los términos allí descritos".
} 
b) Potestades exorbitantes y discrecionales en el ámbito de las sanciones administrativas contractuales

La aplicación de un régimen jurídico de Derecho público implica no solo reconocer un conjunto de reglas y principios, sino que también conlleva el reconocimiento de una serie de potestades inexistentes en un régimen contractual entre privados, como son las potestades exorbitantes (i) y las potestades discrecionales (ii). ${ }^{37}$

\section{(i) Potestades exorbitantes}

Las potestades exorbitantes constituyen uno de los elementos característicos de un contrato administrativo, ${ }^{38}$ conforme a las cuales existe un desequilibrio y una posición dominante por parte del órgano público, lo que claramente es un aspecto distintivo respecto de los contratos privados.

Lo anterior, implica que los tradicionales principios de autonomía de la voluntad e igualdad de las partes quedan atenuados en el contrato administrativo. El primero, debido a que las partes no negocian libremente las cláusulas o condiciones del contrato, sino que éstas son impuestas por la Administración, quedando la voluntad del contratista limitada a aceptar o rechazar su participación en el concurso. ${ }^{39}$ El segundo, debido a que las partes no disponen de las mismas prerrogativas, existiendo una preeminencia de las potestades administrativas, las que, por sus características, reciben la denominación de "exorbitantes".

La fuente de estas potestades se encuentra en el marco normativo que rige el contrato, integrado por la ley, el reglamento, las bases y el contrato

\footnotetext{
${ }^{37} \mathrm{Al}$ efecto, Arancibia sostiene que, aunque las prerrogativas existas en cualquier contrato, el carácter potestativo es intrínseco en las relaciones contractuales entre particulares y el Estado, en ARANCIBIA, Jaime, "Naturaleza y justicia de los contratos administrativos", Revista de Derecho Administrativo Económico, 2019, N 30, pp. 41-42.

${ }^{38}$ Véase Flores Rivas, Juan Carlos, "Revisión de los contratos administrativos: el adecuado equilibrio entre potestades exorbitantes y los derechos contractuales", Revista de Derecho P. Universidad Católica de Valparaíso, 2019, $\mathrm{N}^{\circ} 53$, pp. 66 y ss.

${ }^{39} \mathrm{Al}$ respecto, si bien es posible que en la etapa de preguntas y respuesta se pueda incidir en algún aspecto del régimen aplicable al contrato, es necesario que se cumplan con estrictas medidas de transparencia y publicidad, de manera que la modificación de las bases a través de esta vía sea general para todos los licitantes interesados y no vulnere el principio de estricta sujeción a las bases, en Corte Suprema, 14 de febrero de 2020, "Núcleo Paisajismo S.A. con I. Municipalidad de San Pedro de la Paz", Rol No 22.112-2019. Por su parte, Contraloría ha señalado que es jurídicamente procedente que la Administración, en la etapa de aclaraciones, precise la multa que se impondrá respecto de determinados incumplimientos, sobre todo, en aquellos casos en los cuales existe discordancia entre lo previsto en los distintos documentos que componen el proceso licitatorio, en Oficio $\mathrm{N}^{\mathrm{o}} 6.437$, de 2020.
} 
administrativo. Su fundamento descansa en interés general que se busca satisfacer. ${ }^{40}$

En tal sentido, los tribunales de justicia han señalado que "(...) tratándose en la especie entonces de un contrato administrativo, está sujeto a un régimen especial en que se privilegia el interés general por sobre el particular del contratista. No existe, por ende, una igualdad entre los contratantes, lo que se traduce en la incorporación en este tipo de contratos de las llamadas "cláusulas desorbitantes", pues el objetivo que se persigue es que se ejecuten y finalmente se cumplan íntegramente dichos contratos". ${ }^{41}$

Con estas prerrogativas la Administración asegura la ejecución del contrato. Con todo, en su ejercicio, el órgano debe respetar el carácter bilateral y recíproco del contrato, particularmente, debe velar por la mantención de su equilibrio económico-financiero.

Dentro de las diversas prerrogativas exorbitantes, ${ }^{42}$ cabe destacar, en lo que aquí interesa, la potestad sancionadora, la cual opera en caso de incumplimiento de las obligaciones asumidas por el contratista. Esta potestad tiene por objeto asegurar la efectiva y debida ejecución del contrato. Con todo, la eventual aplicación de sanciones al contratista no excluye la adopción de otras medidas que coadyuven al cumplimiento de tal finalidad.

En concreto, la potestad sancionadora se materializa en el establecimiento en las bases, términos de referencia (TDR) y/o contrato de cláusulas penales o sancionatorias, las que, tal como se señalara supra, tienen su origen y fundamento en la regulación contenida en el artículo 1535 del Código Civil, por cuanto: i) se trata de cláusulas establecidas por una de las partes, a saber, la Administración; ii) con el objeto de

\footnotetext{
${ }^{40} \mathrm{Al}$ respecto, Ferrada sostiene que "Las potestades administrativas son de distinta intensidad y tienen contenido diverso, aunque todas ellas están encaminadas a satisfacer los intereses públicos puestos bajo la tutela de la organización administrativa por el ordenamiento jurídico. Dentro de ellas se pueden destacar las potestades reglamentarias, de ejecución, de revisión de sus actos y sancionatoria, por nombrar las más relevantes, todas potestades exorbitantes de la Administración del Estado y que implican una posición privilegiada de ésta dentro del ordenamiento jurídico justificado en los intereses públicos puestos bajo su cargo", en Ferrada Bórquez, Juan Carlos, "Las potestades y privilegios de la administración pública en el régimen administrativo chileno", Revista de Derecho (Valdivia), 2007, Vol. 20, No 2, pp. 69-94.

${ }^{41}$ Corte de Apelaciones de Santiago, 25 de noviembre de 2015, "Inversiones PMG S.A. con CENABAST”, Rol No 81.608-2015, cons. $9^{\circ}$.

${ }^{42} \mathrm{~V}$. gr. poder de dirección: poder de fiscalización y control; poder de interpretación unilateral de los contratos administrativos; poder de anulación; el ius variandi o poder de modificación del objeto del contrato; poder de resolución, entre otros.
} 
asegurar el cumplimiento de una obligación contractual; iii) sometiendo el incumplimiento a una pena o sanción, que generalmente consiste en el pago de un multa; iv) pena o sanción que opera en caso de no ejecutar o de retardar el cumplimiento de las obligaciones contractuales (infracciones al contrato).

Ahora bien, aun cuando la Administración ejerce esta prerrogativa de manera directa y unilateralmente, sin recurrir a la intervención de un órgano jurisdiccional para la imposición de las cláusulas penales o sancionatorias contractuales, debe dar cumplimiento a diversos principios y garantías para el particular. Al efecto, es necesario que:

- La Administración constituya en mora al contratista;

- El contratista tiene la garantía de impugnar administrativa y judicialmente las sanciones;

- Se observe el principio constitucional de proporcionalidad, para la determinación de las sanciones contractuales;

- El acto que establezca la sanción debe ser fundado, por aplicación supletoria de la LBPA. ${ }^{43}$

En definitiva, la potestad sancionadora junto a las otras potestades exorbitantes son características de los contratos administrativos y corresponden a potestades inusuales en el Derecho privado, por lo que, ejercidas en un contrato de derecho común, resultarían ilícitas por exceder el ámbito de la libertad contractual y contrariar el orden público.

\section{(ii) Potestades discrecionales}

Por su parte, en materia contractual, la Administración dispone de potestades discrecionales consistentes en un amplio margen para que el órgano o servicio público configure infracciones y establezca las sanciones respectivas en las bases de licitación o, en su caso, en los términos de referencia (TDR). Asimismo, esta discrecionalidad también se manifiesta al momento de determinar la sanción aplicable al contratista. ${ }^{44}$

En este régimen, a diferencia de lo que acontece en materia

\footnotetext{
${ }^{43}$ Como se verá infra, en materia de contratación de bienes y servicios dicha exigencia se encuentra establecida expresamente en el artículo 79 ter del Reglamento de la Ley No 19.886 .

${ }^{44} \mathrm{Al}$ respecto, Moraga ha señalado que "el quantum de la sanción usualmente se manifiesta en un ejercicio de poder discrecional de la Administración, que no tiene vinculo directo, objetivo o científico con el perjuicio que la conducta del contratante privado puede significar para la Administración.”, en Moraga, cit. (n. 17), p. 498.
} 
administrativa sancionadora, en donde el principio de legalidad exige que sea la ley la que: a) determine las conductas ilícitas; b) establezca las sanciones, c) disponga del procedimiento sancionador y d) fije criterios de determinación de las sanciones; ${ }^{45}$ en muchos casos la ley solo se ha limitado a establecer un exiguo marco normativo, dejando la configuración de los incumplimientos (tipificación) y sus respectivas sanciones a la Administración, la cual goza, para estos efectos, de un amplio margen de discrecionalidad. ${ }^{46}$

Por ello, dada la amplia discrecionalidad de que dispone la Administración para la configuración de conductas infraccionales, sus sanciones y el procedimiento aplicable, es preciso que las bases y/o términos de referencia regulen con un alto grado de precisión las conductas típicas y sus respectivas sanciones, haciendo una remisión específica a los tipos de sanciones, a la fórmula concreta que se utilizará para su determinación, entre otros aspectos.

En este ámbito las exigencias derivadas del principio de legalidad y tipicidad, como son la previsibilidad y seguridad jurídica, deben penetrar de manera mucho más intensa, exigiendo a la Administración un elevado nivel de certeza de los incumplimientos y sanciones contractuales, para efectos de evitar actuaciones arbitrarias o desproporcionadas. ${ }^{47}$

De este modo, la circunstancia de que la Administración, en el ejercicio de sus potestades discrecionales pueda fijar el contenido de las bases, tipificando, creando o configurando incumplimientos y estableciendo sanciones, no la exonera de cumplir con las reglas y principios básicos que le impone nuestro ordenamiento jurídico, como son, el respeto a la previsibilidad de las conductas sancionables, el tipo de sanciones, la precisión de los mecanismos utilizados para su determinación y garantías

\footnotetext{
${ }^{45}$ Criterio contenido en la sentencia del Tribunal Constitucional, Rol N ${ }^{\circ} 3236-2016$.

${ }^{46}$ En efecto, existen contratos administrativos especiales cuyas normas regulan con un mayor grado de detalle el régimen sancionatorio ( $v$. gr. el contrato de obra pública regulado en el Decreto Supremo $\mathrm{N}^{\circ} 75$ , de 2004, del Ministerio de Obas Públicas), mientras que, en otros, la regulación es más bien limitada, remitiendo a las bases administrativas, un detalle más acabado de las sanciones (v. gr. el contrato de concesión de obra pública, regulado en el Decreto Supremo Nº 900, de 1996, del Ministerio de Obras Públicas o el contrato de suministro y prestación de servicios, contendido en la Ley $\mathrm{N}^{\circ} 19.886$ ).

${ }^{47}$ Vid. oficio $\mathrm{N}^{\circ} 3.106$, de 2020, en el cual se representó la resolución $\mathrm{N}^{\circ} 109$, de 2019, del Comando de Bienestar del Ejército de Chile, que aprobaba las bases de licitación que allí se indica, observando, entre otros aspectos, la falta de claridad respecto de la obligación cuyo incumplimiento sería causal de multa.
} 
procedimentales mínimas. ${ }^{48}$

No atenúa la exigencia anterior, el hecho que el contratista haya aceptado voluntariamente las bases, términos de referencia (TDR) y, en general, el marco normativo aplicable al respetivo contrato, puesto que el particular interesado no incide de ninguna forma en su creación y su voluntad queda supeditada a la aceptación general del aludido marco normativo, sin que pueda influir en la modificación de ninguna disposición o cláusula de las bases o del contrato, respetivamente.

3. Principios y reglas aplicables a las sanciones contractuales según la jurisprudencia administrativa

Aun cuando no existe un desarrollo legal, tanto la doctrina como la jurisprudencia, principalmente administrativa, ${ }^{49}$ se han encargado de reconocer diversos principios y reglas aplicables en materia de sanciones contractuales, precisando el alcance y contenido específico de cada uno de ellos, de lo cual se dará cuenta a continuación.

a) Las sanciones contractuales son de derecho estricto

Al respecto, Contraloría General de la República ha señalado que las sanciones -refiriéndose a la multa aplicada por Carabineros de Chile por el retraso en el cumplimiento de un hito del contrato-, son de derecho estricto, sin que corresponda darles otros alcances ni aplicarlas de modo diferente a lo especificado en la norma que las establece. En efecto, en el dictamen $\mathrm{N}^{\mathrm{o}}$ 18.666, de 2019, el organismo de control sostuvo que:

“(...) las sanciones son de derecho estricto, sin que corresponda darles otros alcances ni aplicarlas de modo diferente a lo especificado en la norma que las establece (aplica dictamen $N^{\circ} 7.482$, de 2019).

Ahora bien, en la especie el pliego de condiciones señaló que para determinar si existía atraso en la entrega de una etapa

\footnotetext{
${ }^{48}$ Con todo, Flores sostiene que las bases de licitación no son el instrumento administrativo adecuado para configurar infracciones y multas administrativas, porque constituyen un acto administrativo de carácter orgánico cuyo campo de acción es servir de norma que disciplina el proceso licitatorio. Para el autor, multa en los contratos administrativos debe tener sustento legal por exigencias máximas de justicia (atendida la afectación de derechos y la necesaria observancia de los principios de certeza jurídica, razonabilidad y proporcionalidad), en FLoRES, cit. (n 16).

${ }^{49}$ Lo anterior por cuanto es bastante habitual que los contratistas recurran a dicha entidad de control para que determine la legalidad de las sanciones contractuales impuestas por la Administración.
} 
se consideraría lo indicado en la carta Gantt aprobada, la que, de conformidad con el documento tenido a la vista, solo contempla el tiempo de que dispone el proveedor para ello.

Luego, teniendo en cuenta que en los documentos que rigieron el proceso concursal en comento no se consideró para la aplicación de multas el tiempo que pudiese demorarse el proveedor para corregir las observaciones efectuadas por el servicio respecto de los productos entregados en cada uno de los hitos del contrato, no ha resultado procedente que Carabineros de Chile considerara este periodo para los efectos de la imposición de dicha medida.

Atendido lo antes expuesto, es menester concluir que Carabineros de Chile debe recalcular la multa aplicada a la empresa recurrente y devolver la suma que se hubiese cobrado en exceso". ${ }^{50}$

Vinculado con lo anterior, Contraloría ha sostenido que la forma en que se determina el incumplimiento contractual se debe encontrar debidamente sustentada. $^{51}$

b) En materia de sanciones contractuales tiene plena vigencia del principio de tipicidad

En materia de contratos administrativos se sostiene la plena vigencia del principio de tipicidad, lo cual exige que tanto la conducta infractora como la sanción asociada deben estar expresamente contenidas en la ley, el reglamento, en las bases o en el propio texto del contrato. ${ }^{52}$ Así, la observancia al principio de tipicidad exige que, frente al incumplimiento del contratista, que no tenga establecido una sanción particular, la Administración se encuentra imposibilitada de sancionar por analogía, puesto que, para efectos punitivos, las estipulaciones contractuales y legales deben ser interpretadas de forma restrictiva..$^{53}$

En otras palabras, cuando ni la ley, ni las bases ni el contrato prevén la "potestad sancionadora" (supuestos de incumplimientos y sus respectivas

\footnotetext{
${ }^{50}$ Carabineros de Chile solicitó la reconsideración de este dictamen, la cual fue rechazada, vid. Contraloría General de la República, Dictamen Nº 8.241 de 2020.

${ }^{51}$ Vid. Contraloría General de la República, Dictamen No E43835 de 2020.

${ }^{52}$ Moraga, cit. (n. 17), p. 503.

${ }^{53}$ Comisión arbitral Concesión Ruta 5, tramo Santiago- Los Vilos, 14.08.2002 considerando III.A
} 
sanciones), no cabe la posibilidad de aplicar sanciones puesto que, si el contrato es regla de Derecho, con efectos vinculantes para ambas partes, y no existe previsión al respecto, no puede ocurrir que una de ellas sancione a la otra. ${ }^{54}$

Por su parte, Contraloría ha señalado que las causales para la aplicación de multas, esto es, las infracciones, deben estar expresamente previstas en las bases. En concreto, el órgano de control sostuvo que:

"(...) las bases de la licitación en examen regularon expresamente la aplicación de las multas, estableciendo que estas proceden si el proveedor excede el plazo contractual dispuesto para la entrega de los bienes, sin que contemplen la posibilidad de imponer multas en el caso de retraso en las entregas parciales que pudiesen haberse pactado". 55

En este mismo sentido, el órgano de control ha sostenido que la aplicación de multas debe ser realizada con estricta sujeción a las bases que rigieron el respectivo proceso concursal, ello por aplicación del principio de estricta sujeción, de los participantes y de la entidad licitante, a las bases administrativas y técnicas que la regulen, que rigen tanto el desarrollo del proceso licitatorio como la ejecución del correspondiente contrato. En tal sentido, señaló que: ${ }^{56}$

“(...) debe recordarse que la estricta sujeción a las bases constituye un principio rector que rige tanto el desarrollo del proceso licitatorio como la ejecución del correspondiente contrato y que dicho instrumento, en conjunto con la oferta del adjudicatario, integran el marco jurídico aplicable a los derechos y obligaciones de la Administración y del proveedor, a fin de respetar la legalidady transparencia que deben primar en los contratos que celebren (aplica dictamen $N^{\circ} 65.769$, de 2014, de este origen).

En este contexto, es menester indicar que el pliego de condiciones que rigió la licitación a que se refieren los interesados reguló expresamente -en su capítulo $X X X$-la materia relacionada con

\footnotetext{
${ }^{54}$ Delpiazzo, Carlos, Contratación Administrativa, Fundación de Cultura Universitaria, Montevideo, 2019, p. 297.

${ }^{55}$ Contraloría General de la República, Dictamen N 7.482 de 2019.

${ }^{56}$ Contraloría General de la República, Dictamen N 10.538 de 2019.
} 
las multas y sanciones a imponer por incumplimiento del proveedor.

Luego, para establecer si en la prestación de los servicios contratados las empresas representadas por los recurrentes incurrieron en conductas que importen incumplimientos de los respectivos convenios, la JUNAEB ha debido estarse a lo previsto en dicho capítulo y a las demás normas de las bases que resulten aplicables (aplica dictamen $N^{\circ} 7.165$, de 2019).

De conformidad con lo anterior, no resulta procedente que el servicio recurrido, con ocasión de la dictación de instrucciones de supervisión, establezca nuevos supuestos para la aplicación de multas, o modifique los mismos, por lo que la JUNAEB debe revisar esos documentos con el objeto de verificar que se ajusten a lo previsto en las bases respectivas".

c) Las acciones para el cobro de las sanciones contractuales prescriben conforme a las normas de derecho común

Sobre el particular, la jurisprudencia administrativa ha indicado que las acciones para el cobro de las multas establecidas en las bases de licitación $\mathrm{y}$ en los respectivos contratos prescriben conforme a las disposiciones del Título XLII "De la Prescripción", del Libro Cuarto "De las obligaciones en general y de los contratos", del Código Civil. ${ }^{57}$

De este modo, las sanciones prescriben en un plazo de cinco años desde que el acto administrativo que las impone ha quedado firme. Sin embargo, la doctrina considera que dicho plazo es excesivo si se compara con el plazo que tienen los particulares para reclamar de la imposición de las multas y con los plazos de prescripción establecidos en otros ámbitos. ${ }^{58}$ Además, esta doctrina no ha profundizado en torno al plazo de prescripción de los incumplimientos o en cuanto a la aplicación de las instituciones de suspensión e interrupción de los plazos.

d) Proporcionalidad

En relación con este principio, la jurisprudencia administrativa ha señalado que su regulación se encuentra en la ley, en concreto, en las normas

\footnotetext{
${ }^{57}$ Contraloría General de la República, Dictamen No 4.508 de 2013; Dictamen № 65.446 de 2013; Dictamen $N^{\circ} 61.075$ de 2016; Dictamen No 74.275 de 2016.

${ }^{58}$ FloRes, cit. (n. 16).
} 
que se refieren a la cláusula penal. En tal sentido, se ha sostenido que si conforme a lo establecido en el artículo 1544 del Código Civil se estima que las multas han resultado desproporcionadas o exorbitantes, ${ }^{59}$ corresponderá a los Tribunales de Justicia moderarlas, siendo, por tanto, un asunto de naturaleza litigiosa que en virtud del artículo $6^{\circ}$ de la Ley $\mathrm{N}^{\circ} 10.336$, resulta ajeno a la competencia de Contraloría. ${ }^{60}$

Sin embargo, antes de recurrir a las normas de Derecho Privado, es preciso observar lo que las disposiciones y principios de Derecho Público han señalado en relación con el principio de proporcionalidad.

El aludido principio se ha transformado en una técnica que tiene por finalidad el control del ejercicio de los poderes públicos de todas las entidades que forman parte de la Administración del Estado, para determinar si su intensidad es, o no, la más adecuada jurídicamente para alcanzar un determinado fin. Este principio ha encontrado su mayor desarrollo y aplicación en el ámbito del Derecho administrativo como un mecanismo destinado a controlar el ejercicio de las potestades discrecionales, alcanzando un rol fundamental en la revisión judicial de las resoluciones administrativas, lo que incluye, ciertamente, a las sanciones administrativas contractuales.

Al efecto, en el caso de las relaciones contractuales, la proporcionalidad desempeña un rol capital. Primero, aparece como un límite que se impone a la Administración al momento de tipificar, crear o configurar las conductas constitutivas de incumplimientos, al determinar su sanción y al establecer el mecanismo para calcularlas. De esta manera, la autoridad debe guardar un adecuado equilibro entre las conductas que considera constitutivas de incumplimiento y su respectiva sanción, de modo que las sanciones que establezca guarden la debida correspondencia con la gravedad de los incumplimientos contractuales cometidos por el contratista.

En otros términos, la entidad de la sanción que aplique el órgano público contratante está condicionada por la gravedad del incumplimiento cometido por el contratista particular. ${ }^{61}$ Así las cosas, un incumplimiento de

\footnotetext{
${ }^{59}$ Sobre las cláusulas abusivas en la contratación pública, véase: LARA, José Luis; HeLFmAnN, Carolina, "Las cláusulas abusivas en la contratación pública: su establecimiento e impugnación", Revista de Derecho de la Empresa (U. Adolfo Ibáñez), 2009, № 19, pp. 123-156.

${ }^{60}$ Contraloría General de la República, Dictamen N 65.791 de 2014.

${ }^{61} \mathrm{Al}$ respecto, cabe tener presente a Contraloría General de la República, Dictamen N ${ }^{\circ}$ E80299 de 2021, en el cual, se analizó los criterios para determinar la multa contenidos en el artículo 86 del Decreto $\mathrm{N}^{\circ} 236$, de 2002, conforme al cual la multa debe determinarse sobre la base del "valor del
} 
escasa importancia debiera tener asignado a una sanción de menor entidad, mientras que una infracción grave debiera tener asignada una sanción de mayor entidad. ${ }^{62}$

En este ámbito el principio encuentra su fundamento en la necesidad de que la sanción no se constituya en una sobrerreacción que torne sumamente gravoso o imposible el cumplimiento del contrato administrativo, puesto que en dicho caso la sanción no sólo afectaría al contratante infractor, sino que sus consecuencias podrían irradiar a quienes se benefician del bien o servicio contratado, afectado la actividad del órgano contratante. ${ }^{63}$

Enseguida, la proporcionalidad es un principio que colabora con la Administración en el ejercicio de sus poderes exorbitantes. En efecto, mediante la aplicación de sanciones en el ámbito contractual la Administración tiene por finalidad asegurar el cumplimiento de lo pactado, garantizando el fin público que comprende el contrato, resguardando el patrimonio público y evitando la repetición de la conducta infractora. En tal sentido, la autoridad deberá ponderar si la aplicación de sanciones contractuales es una medida proporcional a la gravedad del incumplimiento o si, por el contrario, cabe adoptar otras medidas que se determinen, las que deberán encontrarse previamente establecidas en las bases y en el contrato ( $v$. gr. como sería la subsanación de la infracción, el otorgamiento de garantías adicionales, la compensación del incumplimiento, entre otros).$^{64}$

Además, la aplicación de dicho principio obliga a motivar el acto administrativo exponiendo las razones o criterios por los que se adopta una

contrato primitivo y sus ampliaciones", expresión que, atendido su sentido y los principios de buena fe y equilibrio económico del contrato, supone considerar, además de los aumentos de obra, las disminuciones de que haya sido objeto. Sostener lo contrario, importaría el establecimiento de una regla más gravosa para aquellos contratistas cuyos convenios sean objeto de disminución de partidas -ya que estarían afectos a multas proporcionalmente mayores que las que les corresponderían de no mediar tal disminución- lo que pugna con los citados principios.

${ }^{62}$ Moraga, cit. (n. 17), p. 505.

${ }^{63}$ Moraga, cit. (n. 17), p. 505.

${ }^{64}$ En este sentido, se puede citar como ejemplo, el oficio $N^{\circ} 14.772$, de 2014, mediante el cual se cursa con alcances el acto allí señalado, y en el cual se indica que "En cuanto a las multas, reguladas en el $\mathrm{N}^{\circ} 3$ del acto administrativo, se incorpora la posibilidad de que Fonasa pueda graduar el importe de ellas, en función de, entre otros criterios, el número de pacientes afectados por la infracción, y "todo otro criterio proporcional que, a juicio fundado de Fonasa, sea relevante para la determinación de la sanción", facultad que dicha entidad deberá ejercer ponderando especialmente la naturaleza del servicio licitado, el contenido de las causales que dan lugar a multas, la ley $\mathrm{N}^{\circ} 20.584$, que regula los derechos y deberes que tienen las personas en relación con acciones vinculadas a su atención en salud, y el resto de la legislación vinculada a la materia". 
sanción concreta. ${ }^{65}$

También, la proporcionalidad se encuentra vinculada con el quantum de la sanción, por cuanto exige a la Administración considerar el necesario equilibrio que debe existir entre la sanción, el incumplimiento y el monto del contrato, siendo de especial relevancia el establecimiento de criterios que sirvan para determinar las sanciones en cada caso, que permitan apreciar la especial situación fáctica que ha afectado al proveedor en cada supuesto $\mathrm{y}$, eventualmente, los esfuerzos que ha realizado para atenuar los efectos del incumplimiento. En esta última línea se encuentran aquellas sanciones que se establecen según "cada vez" o "cada día", sin límites ${ }^{66}$ y sin el complemento de criterios de determinación de la sanción, lo que puede tornar desproporcionado y no razonable la imposición de la respectiva multa.

Por su parte, la razonabilidad de la multa "por día" o "por evento" también puede depender de la cantidad de días o eventos que la Administración, enterada de la infracción del contratante, deja transcurrir antes de aplicar la sanción. En tal sentido, lo que se espera es que la reacción sancionatoria de la autoridad sea rápida, porque el incumplimiento supone un estado de ilegalidad contractual que se debe remediar. ${ }^{67}$

En tal sentido, una Comisión arbitral de un contrato de concesión de obra pública estimó que se debía reducir una sanción de multa que se había aplicado al concesionario, toda vez que la Administración había dejado pasar 65 días antes de dictarla, teniendo como resultado un incremento significativo de la sanción debido al número de días que dejó transcurrir el órgano público antes de aplicarla. Al efecto, la Comisión sostuvo que la sanción no era razonable si no que injusta y "ajena las intenciones que las partes evidenciaron al contratar". ${ }^{68}$

\footnotetext{
${ }^{65}$ En tal sentido, el inciso final del artículo 79 ter del reglamento de la Ley No 19.886 señala que "La medida a aplicar deberá formalizarse a través de una resolución fundada, la que deberá pronunciarse sobre los descargos presentados, si existieren, y publicarse oportunamente en el Sistema de Información".

${ }^{66}$ Para Flores, estos supuestos pueden generar una reducción de la utilidad del contrato y afectar el principio de equilibro económico del contrato, en Flores, cit. (n. 16).

${ }^{67}$ Moraga, cit. (n. 17), p. 506.

${ }^{68}$ Comisión Arbitral Concesión Terminal de Pasajeros Aeropuerto Chacalluta de Arica (21.06.2012), cons. $15^{\circ}$. Este criterio subyace en las sanciones de los contratos de obra, respecto de los cuales Contraloría ha señalado es dable señalar que, a diferencia de lo señalado que las multas deben hacerse efectivas, preferentemente, en el estado de pago más próximo al incumplimiento respectivo, vid. oficio de representación $\mathrm{N}^{\circ} 4.986$, de 2020.
} 
e) Non bis in ídem y la necesidad de un único fundamento jurídico

Este principio prohíbe la doble sanción de un mismo sujeto, por los mismos hechos y fundamentos jurídicos. Tiene por objeto impedir que un hecho que ha sido sancionado o que ha servido de base para la agravación de una sanción sea utilizado nuevamente. De este modo, si un hecho ya ha sido tomado en consideración para la aplicación de una pena o circunstancia modificatoria de responsabilidad, no es lícito volver a tenerlo en cuenta por segunda o ulterior vez para los mismos efectos. ${ }^{69}$

En materia de sanciones contractuales, se ha discutido su aplicación respecto de una supuesta incompatibilidad entre la aplicación de una multa por atraso en la entrega de especies y la suspensión del contratista del registro electrónico a cargo de la Dirección de Compras y Contratación Pública. Sobre el particular, Contraloría ha sostenido que no resulta posible argumentar una vulneración al principio del non bis in ídem frente a la aplicación de tales medidas, toda vez que la relación jurídica que une al servicio adquirente con el contratante es distinta a la que vincula a este último con la Dirección por lo que la multa y la suspensión del referido registro electrónico de proveedores surgen del incumplimiento de obligaciones distintas. ${ }^{70}$

De esta manera, para la aplicación del principio, se exige la identidad de fundamento de los incumplimientos imputados.

f) Sobre la vigencia del principio de oportunidad en materia de sanciones contractuales

Al respecto, Contraloría ha señalado que la Administración se encuentra en el imperativo de cursar una multa contenida en el contrato cuando se han verificado las causales de incumplimiento pertinentes, atendido el principio de interdicción de la arbitrariedad y el debido resguardo de los intereses fiscales. ${ }^{71}$ En otros términos, constatada la ocurrencia de una infracción contractual, resulta obligatorio para el órgano respectivo la imposición de

\footnotetext{
${ }^{69}$ Sobre el non bis in ídem en materia administrativa sancionadora véase GómEz, Rosa Fernanda, "El non bis in ídem en el derecho administrativo sancionador. Revisión de sus alcances en la jurisprudencia administrativa", Revista de Derecho P. Universidad Católica de Valparaíso, 2017, № 49, pp.101-138.

${ }^{70}$ Contraloría General de la República, Dictamen No 30.003 de 2014; Dictamen Nº 65.788 de 2014; Dictamen $\mathrm{N}^{\circ} 65.791$ de 2014.

${ }^{71}$ Contraloría General de la República, Dictamen № 23.048 de 2011; Dictamen $N^{\circ} 23.050$ de 2011; Dictamen $N^{\circ} 26.232$ de 2011; Dictamen $N^{\circ} 56.887$ de 2011; Dictamen $N^{\circ} 96.251$ de 2015.
} 
una determinada sanción pecuniaria. ${ }^{72}$

Lo anterior debe ser necesariamente matizado, debido a que bien puede la Administración no iniciar un procedimiento sancionatorio contractual si estima que el incumplimiento: i) no tiene una trascendencia jurídica relevante; ii) no afecta o pone en peligro el fin público que busca garantizar el contrato; iii) no se ha afectado el patrimonio fiscal; o iv) cuando el contratista infractor ofrece propuestas de solución. ${ }^{73}$

Lo anterior encuentra su fundamento en los principios de eficacia, eficiencia, celeridad, economía procedimental, buena fe contractual y proporcionalidad. En efecto, en muchas ocasiones la Administración debe ponderar si la aplicación de las sanciones, atendida la entidad del incumplimiento, es procedente o si, en su caso, la adopción de medidas alternativas a la sanción puede resultar más convenientes para la satisfacción del interés general.

g) Sobre la necesidad de un procedimiento administrativo previo a la aplicación de sanciones contractuales

Sobre el particular, Contraloría General de la República ha sostenido que las bases administrativas deben regular, con un alto grado de detalle y previsibilidad, el procedimiento de aplicación de multa, evitando incurrir en "(...) imprecisiones que imposibilitan su aplicación con la debida certeza". ${ }^{74}$

La necesidad de un procedimiento previo también ha sido sostenida en el Oficio $\mathrm{N}^{\circ} 8.624$, de 2020, por medio del cual Contraloría hace presente que, de forma previa a disponer las medidas de multa allí previstas, se deberá iniciar el proceso sancionatorio contemplado en las mismas bases.

Enseguida, la sanción contractual, como todo acto administrativo, debe ser motivado. La motivación exige que la sanción se base en razones objetivas y comprobables que permitan su íntegra comprensión,

${ }^{72}$ Contraloría General de la República, Dictamen N 65.248 de 2011; Dictamen N 8.297 de 2012; Dictamen $N^{\circ} 13.354$ de 2012; Dictamen $N^{\circ} 31.848$ de 2014; Dictamen $N^{\circ} 65.788$ de 2014, y Dictamen $\mathrm{N}^{\circ} 1.765$ de 2015.

${ }^{73}$ Vid. Bases de licitación y los TDR de CENABAST, en los cuales se establece que en forma previa a la comisión de la falta -o tan pronto tome conocimiento de la situación para el evento que ésta no pueda preverse- el proveedor podrá plantear la CENABAST propuestas de solución, y si alguna de ellas es aceptada, la sanción que se hubiese aplicado quedará suspendida condicionalmente, en Contraloría General de la República, Dictamen No 41.551 de 2015, y Dictamen No 82.241 de 2015.

${ }^{74}$ Contraloría General de la República, Dictamen No 12.309 de 2019. En este caso, dicho vicio, junto a otros, dieron lugar a la representación de las resoluciones enviadas al trámite de toma de razón. 
especialmente cuando la autoridad ejerce su potestad sancionatoria en materia contractual. Al efecto, la Corte Suprema ha señalado que "(...) el fin último de la exigencia de motivación de todo acto administrativo no es otro que requerir la explicitación de sus fundamentos racionales, de manera tal que sean comprensibles para el administrado, proveyéndole la información necesaria para que, en caso de disconformidad o agravio, ejerza adecuadamente los mecanismos recursivos que le franquea la ley, tanto ante la Administración como la jurisdicción". ${ }^{75}$

Por su parte, la Corte Suprema ha señalado que una multa erróneamente determinada, a partir de una equívoca interpretación de la forma para computar el plazo para calcularla conforme al procedimiento sancionatorio establecido en las bases administrativas, puede dar lugar a la indemnización de perjuicios en favor del contratista. ${ }^{76}$

En definitiva, queda proscrita la aplicación automática de multas, siendo necesaria la tramitación de un procedimiento previo en el cual se notifique al contratista el incumplimiento respectivo y se le otorgue un plazo para subsanarlo (en caso de disponerlo las bases) y/o, en su caso, para presentar descargos dentro de un término razonable. De acreditarse la ocurrencia de la contravención, la autoridad aplicará la multa mediante la dictación de un acto administrativo motivado el cual podrá ser impugnado administrativa y/o judicialmente.

\section{REVISIÓN DEL RÉGIMEN SANCIONADOR DEL CONTRATO DE SUMINISTRO Y PRESTACIÓN DE SERVICIOS}

A lo largo de este trabajo se ha sostenido que las sanciones administrativas o cláusulas penales establecidas en los contratos administrativos, deben regirse por un régimen jurídico de Derecho público, conformado por diversas garantías y principios propios al ejercicio de potestades públicas, lo cual adquiere especial relevancia tratándose de contratos administrativos, en donde la configuración de incumplimientos

\footnotetext{
${ }^{75}$ Corte Suprema, 18 de marzo de 2021, "Cas Chile S.A. con I. Municipalidad de Villa Alemana", Rol $\mathrm{N}^{\mathrm{o}} 39.624-2020$, cons. $12^{\circ}$.

${ }^{76}$ Corte Suprema, 23 de julio de 2020, "Servicios Sitrack Chile Ltda. con I. Municipalidad de Santiago", Rol No 24.212-2019.
} 
y el establecimiento de sanciones responde al ejercicio de una potestad exorbitante de carácter discrecional. Lo anterior es sin perjuicio de recurrir, en lo no regulado, a normas de Derecho privado.

También, se ha señalado que este régimen de Derecho público no es muy distinto al reconocido en el Derecho administrativo sancionador, por cuanto, ambos sistemas comparten la ausencia de una norma general o de base que establezca las reglas y garantías específicas de protección y resguardo de los derechos de los sujetos pasivos de la potestad.

En parte, el recurso al régimen administrativo sancionador, sin atender a las particularidades propias de la relación jurídica contractual, permite explicar las reacciones dispares tanto entre la doctrina como en la jurisprudencia.

A continuación, se analiza el particular régimen sancionador establecido en la Ley N ${ }^{\circ}$ 19.886, de Bases sobre Contratos Administrativos de Suministro y Prestación de Servicios, dado que se trata del contrato más común a nivel administrativo. Si bien su marco regulatorio en la materia es precario, destaca la labor de racionalización efectuada por su reglamento, el cual ha reconocido una base mínima para la aplicación de las sanciones contractuales, a partir de los diversos principios y garantías aplicables en materia de Derecho público en general.

\section{Aspectos generales}

El artículo $1^{\circ}$ de la Ley $\mathrm{N}^{\mathrm{o}} 19.886$, prescribe que a los contratos administrativos que dicha norma regula se les aplicarán las disposiciones de ese cuerpo legal, supletoriamente las normas de Derecho Público, y en defecto de aquellas, las normas de Derecho Privado. Enseguida, el artículo 11 inciso $3^{\circ}$ establece que con cargo a la garantía que asegure el fiel y oportuno cumplimiento del contrato, podrán hacerse efectivas las multas y demás sanciones que afecten a los contratistas, disposición que se reitera en el $\mathrm{N}^{\circ} 6$ del artículo 22 del reglamento.

Esos preceptos reconocen la posibilidad de que la Administración contemple multas en la contratación que tenga por objeto adquirir bienes y servicios, aun cuando ninguno de ellos las regula expresamente. ${ }^{77}$ Por consiguiente, resulta esencial su establecimiento a nivel de bases, en donde

${ }^{77}$ Contraloría General de la República, Dictamen Nº 34.523 de 2013; Dictamen Nº 65.731 de 2013. 
se indiquen las condiciones de aplicación de sanciones y se exprese la forma en que se determinará su cuantía. ${ }^{78}$

En este ámbito, la principal sanción será la multa, la cual se podrá imponer por atrasos o por la entrega o prestación defectuosa del bien o servicio. La aplicación de la medida estará a cargo del jefe de servicio, quien, en la ejecución de tal cometido, deberá respetar las disposiciones de la Ley $\mathrm{N}^{\circ} 19.886$ y su reglamento, así como también los principios generales que informan la contratación pública, entre los cuales se encuentra la estricta sujeción a las bases.

\section{Aspectos sustantivos y procedimentales de la aplicación de sanciones}

Mediante el Decreto $N^{0}$ 1410, de 2015, del Ministerio de Hacienda, se modificó el reglamento de la Ley $\mathrm{N}^{\circ}$ 19.886, incorporando el artículo 79 ter, disposición que establece que en caso de incumplimiento por parte de los proveedores de una o más obligaciones establecidas en las bases y en el contrato, la entidad contratante podrá adoptar alguna de las siguientes medidas: i) aplicar multas: ii) cobrar la garantía de fiel cumplimiento: iii) terminar anticipadamente el contrato o iv) adoptar otras medidas que se determinen, las que deberán encontrarse previamente establecidas en las bases y en el contrato.

El mismo precepto dispone que las medidas que se establezcan deberán ser proporcionales a la gravedad del incumplimiento. Por ello, precisa que, si la medida a aplicar consistiere en el cobro de multas, las bases y el contrato deberán fijar un tope máximo para su aplicación, aunque no especifica dicho tope.

A nivel comparado, por ejemplo, en España, la ley se encarga de precisar los límites para la fijación de sanciones. Así, el artículo 192.1 de la Ley $9 / 2017$, de 8 de noviembre, de Contratos del Sector Público, señala que los pliegos o el documento descriptivo podrán prever penalidades para el caso de cumplimiento defectuoso de la prestación objeto del mismo o para el supuesto de incumplimiento de los compromisos o de las condiciones especiales de ejecución del contrato que se hubiesen establecido. Estas penalidades deberán ser proporcionales a la gravedad del incumplimiento y

\footnotetext{
${ }^{78}$ Contraloría General de la República, Dictamen Nº 65.731 de 2013; Dictamen N 77.765 de 2013; Dictamen $N^{\circ} 3.485$ de 2014.
} 
las cuantías de cada una de ellas no podrán ser superiores al 10\% del precio del contrato, IVA excluido, ni el total de las mismas superar el $50 \%$ del precio del contrato.

Por el contrario, en nuestro ordenamiento, hasta la reforma de 2015, ni la ley ni el reglamento establecían un límite al monto máximo al que podrían ascender las sanciones de multa, la cuales, en algunos casos, podría exceder el monto total del contrato. ${ }^{79}$ Con la modificación del reglamento, se incorpora la exigencia de fijar un límite ${ }^{80} \sin$ embargo, no se indica cuál debe ser. ${ }^{81}$

Por su parte, aun cuando la norma hace referencia a la proporcionalidad que debe existir al momento de fijar la cuantía o la fórmula de cálculo de las sanciones contractuales, no se debe olvidar que la exigencia de proporcionalidad también debe regir al momento de aplicar la sanción.

Desde la perspectiva procedimental, se exige que las bases y el contrato deban contemplar un procedimiento para la aplicación de las medidas establecidas para los casos de incumplimiento (lo que incluye las multas), ${ }^{82}$ el cual deberá respetar los principios de contradictoriedad e impugnabilidad del acto administrativo. ${ }^{83}$

Junto con ello, el procedimiento siempre deberá conceder traslado al respectivo proveedor, ${ }^{84}$ a fin de que éste manifieste sus descargos en relación

\footnotetext{
${ }^{79}$ Véase Contraloría General de la República, Dictamen N No 34.523 de 2013, en donde la multa ascendió a \$25.605.320, que resultó mayor al valor de la obligación principal de \$15.708.785.

${ }^{80} \mathrm{Al}$ efecto, Contraloría ha exigido que las bases administrativas deben establecer el tope máximo general para la aplicación de las multas, vid. Contraloría General de la República, Dictamen N 31.840 de 2016; Dictamen N 37.168 de 2016; y Dictamen № 56.476 de 2016.

${ }^{81}$ Según un estudio, hasta el año 2013 los convenios marco no establecían límites a la cuantía de las multas y los que las fijan, sólo un 10\% establecía como tope el $50 \%$ del valor del contrato, mientras que el porcentaje restante fija un 30\%. Véase en Lara y García-Huidobro, cit. (n. 16), pp. 390 y ss.

${ }^{82}$ Sobre el particular, Contraloría General de la República, Oficio No 2.453 de 2018, que Imparte instrucciones sobre el cumplimiento del principio de probidad en materia de contratación pública de suministro de bienes muebles y prestación de servicios, señaló que "Las entidades deben establecer los criterios y mecanismos para la evaluación y gestión de los contratos que celebren y, en su caso, la aplicación de las medidas por incumplimiento, tales como término anticipado y multas (artículos $4^{\circ}$, 77 y 79 ter del reglamento).”.

${ }^{83}$ Sobre el particular, Contraloría ha representado los actos que no contemplan un procedimiento de aplicación de multas (vid. Contraloría General de la República, Dictamen N 77.047 de 2015; Dictamen $\mathrm{N}^{\circ} 95.413$ de 2015; Dictamen $\mathrm{N}^{\circ} 102.648$ de 2015; Dictamen $\mathrm{N}^{\circ} 21.972$ de 2016; Dictamen $\mathrm{N}^{\circ} 945$ de 2017), así como aquéllos que omitan señalar que en contra de la resolución que aplique una multa proceden los recursos contemplados en la ley N 19.880 (vid. Contraloría General de la República, Dictamen $\mathrm{N}^{\circ} 80.519$ de 2015).

${ }^{84}$ Contraloría General de la República, Dictamen N 93.774 de 2016.
} 
con el eventual incumplimiento. La medida a aplicar deberá formalizarse a través de una resolución fundada, ${ }^{85}$ la que deberá pronunciarse sobre los descargos presentados, si existieren, y publicarse oportunamente en el Sistema de Información. ${ }^{86}$ Enseguida, el reglamento establece que en contra de dicha resolución procederán los recursos dispuestos en la Ley $\mathrm{N}^{\circ} 19.880$.

En cuanto a la ejecución de las multas, se podrán hacer efectivas, total o parcialmente, sobre cualquier estado de pago o del documento bancario de garantía de fiel y oportuno cumplimiento del contrato. Por tanto, mientras permanezcan obligaciones pendientes por parte del proveedor derivadas del contrato, como sería el pago de las multas, la Administración deberá velar por que la garantía de fiel cumplimiento se mantenga vigente. ${ }^{87}$

En definitiva, mediante la modificación del reglamento, se ha racionalizado, en alguna medida, el ejercicio de la potestad sancionadora que tiene la Administración durante la ejecución de los contratos de esta naturaleza, estableciendo reglas sustantivas y procedimentales que constituyen un conjunto de garantías para los contratistas. ${ }^{88}$

\section{CONCLUSIONES}

De lo expuesto, es posible establecer que, en general, las leyes sobre contratación pública escasamente se han preocupado de los aspectos sustantivos y procedimentales de las sanciones contractuales, dejando la configuración de los incumplimientos, la regulación de las sanciones y su procedimiento de aplicación a la Administración contratante, la cual deberá definirla, conforme a sus potestades exorbitantes y de manera discrecional, en las bases de licitación, términos de referencia y, en su caso, en el contrato respectivo.

La discusión más relevante dice relación con la naturaleza jurídica de las sanciones contractuales y el régimen jurídico aplicable, en donde

\footnotetext{
${ }^{85}$ Contraloría General de la República, Dictamen Nº 74.194 de 2016.

${ }^{86}$ Registro de Proveedores, artículo 96 bis del Reglamento.

${ }^{87}$ Contraloría General de la República, Dictamen N 34.523 de 2013.

${ }^{88}$ En la actualidad se encuentra en tramitación un proyecto de ley cuyo objeto es modificar sustantivamente la Ley N 19.886 (Boletín 14137-05), para mejorar la calidad del gasto público, aumentar los estándares de probidad y transparencia e introducir principios de economía circular en las compras del Estado, sin embargo, no contempla ninguna modificación en materia de sanciones contractuales.
} 
podemos encontrar diversas posiciones tanto a nivel dogmático como jurisprudencial.

En concreto, en este trabajo se sostiene que, más allá de su denominación, estamos frente a sanciones de carácter administrativo, sin que por ello automáticamente pasen a formar parte del denominado "Derecho administrativo sancionador", al cual se ha recurrido, principalmente, debido al régimen de derechos y garantías que ofrece a los particulares contratistas.

En otros términos, lo que se sostiene es que, tratándose de sanciones administrativas contractuales, se debe observar un conjunto de reglas, principios y garantías de Derecho público, tales como legalidad, contradictoriedad, proporcionalidad, motivación e impugnabilidad, los cuales son comunes al ejercicio de toda potestad pública.

Lo anterior queda de manifiesto con las modificaciones introducidas al reglamento de la Ley $\mathrm{N}^{\mathrm{o}} 19.886$, en donde se ha procurado racionalizar la aplicación de sanciones contractuales mediante el establecimiento de una serie de principios sustantivos y reglas procedimentales propias de dicho orden.

Sin embargo, aun quedan muchos aspectos a regular, particularmente los límites a la discrecionalidad que posee la Administración para configurar e imponer sanciones contractuales, los cuales bien podrían ser regulados en normas de rango legal como garantía de seguridad jurídica para los particulares.

\section{BIBLIOGRAFÍA CITADA}

\section{a) Doctrina}

Alarcón, Pablo, "Sanciones Administrativas en el Contrato de Construcción de Obra Publica", en Arancibia, Jaime; Alarcón, Pablo (coord.), Sanciones Administrativas, Legal Publishing, Santiago, 2014, pp. 361-368.

AranciBIA, Jaime, "Naturaleza y justicia de los contratos administrativos", Revista de Derecho Administrativo Económico, 2019, No 30, pp. 27-53.

BermúdEz, Jorge, Derecho administrativo general, Legalpublishing, Thomson Reuters-La Ley, Santiago, 2014, $3^{\text {a }}$ edición.

Corral, Hernán, "La cláusula penal en la resolución del contrato" en Alcalde, Enrique; Fábrega, Hugo (coords.), Estudios jurídicos en homenaje a Pablo Rodríguez Grez, Universidad del Desarrollo, Santiago, 2009. 
Corral, Hernán, La “cláusula penal”. Función y eficacia del contrato penal en el Derecho Chileno, Editorial Jurídica de Chile, Santiago, 2012.

Delpiazzo, Carlos, Contratación Administrativa, Fundación de Cultura Universitaria, Montevideo, 2019.

FARRANDO, Ismael, "Sanciones contractuales", en FARRANDO, Ismael (Dir.), Contratos Administrativos, Lexis Nexis, Buenos Aires, 2002.

FERrADA, Juan Carlos, "Las potestades y privilegios de la administración pública en el régimen administrativo chileno", Revista de Derecho (Valdivia), 2007, Vol. 20, N 2, pp. 69-94.

Flores Rivas, Juan Carlos, "Revisión de los contratos administrativos: el adecuado equilibrio entre potestades exorbitantes y los derechos contractuales", Revista de Derecho - P. Universidad Católica de Valparaíso, 2019, № 53, pp. 67-98.

FLORES, Juan Carlos, “SSon cláusulas penales las multas en los contratos administrativos?", Contratación Administrativa Práctica, 2021, n 173, pp. 137151.

Gómez, Rosa Fernanda, "El non bis in idem en el derecho administrativo sancionador. Revisión de sus alcances en la jurisprudencia administrativa", Revista de Derecho - P. Universidad Católica de Valparaíso, 2017, № 49, pp.101-138.

Lledó, Camilo; PARdo, José, "Sistema de sanciones por incumplimiento en los contratos públicos de suministro y prestación de servicios: la incerteza como un problema de política pública", Revista de Derecho Público, 2015, Vol. 82, pp. 53-77.

LARA, José Luis; GarcíA-Huidobro, Luis Eugenio, "Naturaleza jurídica y proporcionalidad de las multas en la contratación administrativa bajo la Ley $\mathrm{N}^{\circ}$ 19.886", en Arancibia, Jaime; Alarcón, Pablo (coords.), Sanciones Administrativas, Legal Publishing, Santiago, 2014, pp. 369-400.

Lara, José Luis; Helfmann, Carolina, "Las cláusulas abusivas en la contratación pública: su establecimiento e impugnación", Revista de Derecho de la Empresa (U. Adolfo Ibáñez), 2009, No 19, pp. 123-156.

Moraga, Claudio, Contratación administrativa, Thomson Reuters, Santiago, 2019, $2^{\mathrm{a}}$ ed.

Muñoz Machado, Santiago, Tratado de Derecho Administrativo y Derecho Público general, Boletín Oficial del Estado, Madrid, 2015, Tomo XIII (Contratos del Sector Público), $4^{\mathrm{a}}$ edición.

PrAdo, Arturo, "Algunos aspectos de la cláusula penal en el derecho chileno", Revista de Derecho Universidad Católica del Norte, 2019, Vol. No 26, e3893.

RuFiÁn, Dolores, Manual de concesiones de obra pública, Fondo de Cultura Económica, Santiago, 1999.

Ruiz, Andrés, "Límites a la facultad para establecer sanciones en los 
contratos de la Ley 19.886", en Bermúdez, Jorge (editor), Perspectivas para la modernización del Derecho de la contratación administrativa, Ediciones Universitarias de Valparaíso, Valparaíso, 2016, pp. 291-297.

Santamaría Pastor, Juan Alfonso, Principios de Derecho Administrativo General, Iustel, Madrid, 2016, $4^{\mathrm{a}}$ edición, p. 268.

SayaguÉs, Enrique, Tratado de Derecho Administrativo, Fundación de Cultura Universitaria, Montevideo, 2015, Vol. I, 10ª edición, p. 571.

\section{b) Legislación}

Decreto Supremo No 900, de 1996, del Ministerio de Obras Públicas, Fija Texto Refundido, Coordinado y Sistematizado del DFL MOP N 164, de 1991, Ley De Concesiones de Obras Publicas.

Decreto Supremo No 100, de 2005, del Ministerios Secretaría General de la Presidencia, fija el texto refundido coordinado y sistematizado de la Constitución Política de la República de Chile

Decreto con Fuerza de Ley $N^{o}$ 1, del 2000, del Ministerio de Justicia, Fija texto refundido, coordinado y sistematizado del Código Civil.

Ley $\mathrm{N}^{\circ}$ 19.880, Ley de Bases de los Procedimientos Administrativos que rigen los actos de los órganos de la Administración del Estado, de mayo de 2003.

Ley $N^{\circ} 19.886$, Ley de Bases sobre Contratos Administrativos de Suministro y Prestación de Servicios, de julio de 2003.

Decreto $\mathrm{N}^{\circ} 250$, de 2004, del Ministerio de Hacienda, Reglamento de la Ley No 19.886 .

Decreto $N^{0} 75$, de 2004, del Ministerio de Obras Públicas que aprueba el Reglamento para Contratos de Obras Públicas.

Ley española de Contratos del sector Público, texto refundido aprobado por Real Decreto Legislativo 3/2011, de 14 de noviembre de 2011.

\section{c) Jurisprudencia}

\section{i.- Jurisprudencia Administrativa} 1985.

Contraloría General de la República, Dictamen N N 1.307, 15 de enero de

Contraloría General de la República, Dictamen No 23.309, de octubre de 1986. 1997.

Contraloría General de la República, Dictamen $N^{o}$ 12.523, 23 de abril de

Contraloría General de la República, Dictamen $\mathrm{N}^{\mathrm{o}} 26.263,20$ de mayo de 2009. 2011. 
Contraloría General de la República, Dictamen № 72.427, 21 de noviembre de 2011.

Contraloría General de la República, Dictamen $N^{0} 23.048,14$ de abril de 2011. 2011.

Contraloría General de la República, Dictamen $N^{0}$ 23.050, 14 de abril de

Contraloría General de la República, Dictamen No 26.232, 28 de abril de 2011.

Contraloría General de la República, Dictamen No $56.887,7$ de septiembre de 2011.

Contraloría General de la República, Dictamen Nº 65.248, 17 de octubre de 2011.

Contraloría General de la República, Dictamen Nº 8.297, 10 de febrero de 2012.

Contraloría General de la República, Dictamen $N^{0} 13.354,7$ de marzo de 2012. 2002

Contraloría General de la República, Dictamen $N^{0}$ 21.035, 12 de abril de 2012.

Contraloría General de la República, Dictamen No 49.409, 13 de agosto de Contraloría General de la República, Dictamen № 50.606, 17 de agosto de 2012. 2013.

Contraloría General de la República, Dictamen N 4.508, 22 de enero de

Contraloría General de la República, Dictamen No 34.523, 4 de junio de 2013. 2013.

Contraloría General de la República, Dictamen No 47.611, 26 de julio de

Contraloría General de la República, Dictamen No $65.446,10$ de octubre de 2013. 2013.

Contraloría General de la República, Dictamen No $65.731,11$ de octubre de

Contraloría General de la República, Dictamen $N^{0} 77.765,27$ de noviembre de 2013.

Contraloría General de la República, Dictamen $N^{0} 3.485,15$ de enero de 2014.

Contraloría General de la República, Dictamen No 30.003, 9 de abril de 2014.

Contraloría General de la República, Dictamen $N^{0} 31.848,7$ de mayo de 2014.

Contraloría General de la República, Dictamen No 65.788, 27 de agosto de 2014. 

2014.

Contraloría General de la República, Dictamen № 65.791, 27 de agosto de

Contraloría General de la República, Dictamen N ${ }^{\circ} 1.765,9$ de enero de 2015.

Contraloría General de la República, Dictamen No 41.551, 26 de mayo de 2015.

Contraloría General de la República, Dictamen No 50.347, 23 de junio de 2015. 2015.

Contraloría General de la República, Dictamen N $N^{0} 56.435,15$ de julio de

Contraloría General de la República, Dictamen $N^{\circ} 77.047,28$ de septiembre de 2015 .

Contraloría General de la República, Dictamen N No $^{\circ} 2.241,28$ de septiembre de 2015 .

Contraloría General de la República, Dictamen $N^{\circ} 80.519,28$ de octubre de 2015.

Contraloría General de la República, Dictamen $N^{\circ} 95.413,1$ de diciembre de 2015.

Contraloría General de la República, Dictamen $N^{\circ} 96.251,3$ de diciembre de 2015.

Contraloría General de la República, Dictamen $N^{\circ} 102.648,30$ de diciembre de 2015 .

Contraloría General de la República, Dictamen $N^{\circ} 21.972,22$ de marzo de 2016.

Contraloría General de la República, Dictamen $\mathrm{N}^{\circ} 31.840,28$ de abril de 2016. 2016.

Contraloría General de la República, Dictamen № 61.075, 18 de agosto de

Contraloría General de la República, Dictamen № 74.194, 7 de octubre de 2016.

Contraloría General de la República, Dictamen N $N^{0} 74.275,7$ de octubre de 2016.

Contraloría General de la República, Dictamen N 93.774, 29 de diciembre de 2016.

Contraloría General de la República, Dictamen N 945, 11 de enero de 2017. 2017.

Contraloría General de la República, Dictamen No 37.515, 23 de octubre de

Contraloría General de la República, Dictamen No 40.163, 14 de noviembre de 2017.

Contraloría General de la República, Dictamen No 27.910, 12 de noviembre de 2018 . 
Contraloría General de la República, Dictamen No 27.913, 12 de noviembre de 2018 .

Contraloría General de la República, Dictamen $N^{\circ} 31.421,18$ de diciembre de 2018.

Contraloría General de la República, Dictamen $N^{\circ} 7.482,14$ de marzo de 2019.

Contraloría General de la República, Dictamen $N^{\circ} 10.538,16$ de abril de 2019.

Contraloría General de la República, Dictamen $N^{\circ} 12.309,7$ de mayo de 2019.

Contraloría General de la República, Dictamen No 8.241, 23 de abril de 2020.

Contraloría General de la República, Dictamen No E43835, 16 de octubre de 2020.

Contraloría General de la República, Dictamen Nº E80299, 24 de febrero de 2021.

\section{ii.- Jurisprudencia Constitucional}

Tribunal Constitucional, 24 de mayo de 2018, Rol N³236-2016.

\section{iii.- Jurisprudencia Judicial}

Corte de Apelaciones de Santiago, 17 de julio de 2014, "Nipro Medical Corporation con CENABAST", Rol N 93.869-2013.

Corte de Apelaciones de Santiago, 17 de julio de 2014, "Nipro Medical Corporation con CENABAST (II)", Rol N 148.668-2013.

Corte de Apelaciones de Santiago, 25 de noviembre de 2015, "Inversiones PMG S.A. con CENABAST”, Rol N 81.608-2015.

Corte Suprema, 30 de enero 2017, "De Marco S.A. con I. Municipalidad de Maipú", Rol No 16.629-2016.

Corte Suprema, 21 de diciembre de 2017, “Espacio y Jardín Ltda. con I. Municipalidad de Iquique", Rol No 4.001-2017.

Corte Suprema, 18 de octubre de 2018, "Mellafe y Salas S.A. con Fisco de Chile", Rol No 38.856-2017.

Corte Suprema, 4 de diciembre de 2018, "Sodexo Servicios S.A. con JUNAEB", Rol No 45.578-2017.

Corte Suprema, 24 de julio de 2019, "Duarte Parada con SERVIU Metropolitano", Rol No 5218-2018.

Corte Suprema, 25 de julio de 2019, "CAS Chile S.A. con I. Municipalidad de La Pintana", Rol N 11.527-2019.

Corte Suprema, 8 de noviembre 2019, "Scolarest S.A. con JUNAEB", Rol $\mathrm{N}^{\mathrm{o}} 16.345-2018$. 
Corte Suprema, 24 de enero de 2020, "Concesiones Recoleta S.A. con I. Municipalidad de Recoleta", Rol No 251-2019.

Corte Suprema, 14 de febrero de 2020, "Núcleo Paisajismo S.A. con I. Municipalidad de San Pedro de la Paz", Rol No 22.112-2019.

Corte Suprema, 23 de julio de 2020, "Servicios Sitrack Chile Ltda. con I. Municipalidad de Santiago", Rol No 24.212-2019.

Corte Suprema, 18 de marzo de 2021, "Cas Chile S.A. con I. Municipalidad de Villa Alemana”, Rol No39.624-2020. 